\title{
PENGARUH PENGGUNAAN MEDIA KOMIK MATEMATIKA DENGAN BANTUAN POWERPOINT TERHADAP MOTIVASI DAN HASIL BELAJAR MATEMATIKA SISWA DI SMK ISTIQLAL DELITUA
}

\author{
Putri Amanda Siregar', Rosliana Siregar ${ }^{2}$ \\ ${ }^{1}$ Program Studi Pendidikan Matematika FKIP Universitas Islam Sumatera Utara \\ ${ }^{2}$ Dosen Koopertis Wil. I. Dpk FKIP Universitas Islam Sumatera Utara \\ ${ }^{1}$ Putri.amandasiregar@yahoo.co.id, ${ }^{2}$ Roslianasrg@ fkip.uisu.ac.id
}

\begin{abstract}
This research aims to determine the effect of using comics media mathematics with the help of powerpoint on motivation and results of students' mathematics learning on the subject of the matrix inverse order $2 \times 2$. This research was conducted in SMK Istiqlal Delitua. The population in this research are 486 students of class $X$. The sampling in this research using purposive sampling technique are 35 students of class X.AP-1. Based on the results of the test data requirements known that motivation data as well as results of the students' mathematic learning are distributed normally. Motivation data an average score is 99,2 while the results of students' mathematics learning data an average score is 19,6. Based on data analysis known that: (1) comics media mathematics are positive and significant impact on motivation to mathematic learn, where t test was obtained $t_{\text {hitung }}=3,1914>t_{\text {tabel }}=1,692$. The index determination $I=12,5 \%$, it means that comics media mathematics accounted 12,5\% with motivation onof mathematic learning; (2) comics media mathematics are positive and significant with the results of students' mathematics learning. Based on t test was obtained $t_{\text {hitung }}=6,19>t_{\text {tabel }}=1,692$. The index determination $I=53,77 \%$, it means that comics media mathematics accounted for $53,77 \%$ of the increase in the results of students' mathematics learning.
\end{abstract}

Keywords: media comic math, motivation to learn, learning outcomes

\begin{abstract}
Abstrak. Penelitian ini bertujuan untuk mengetahui pengaruh penggunaan media komik matematika dengan bantuan powerpoint terhadap motivasi dan hasil belajar matematika pada pokok bahasan invers matriks ordo $2 \times 2$. Penelitian ini dilaksanakan di SMK Istiqlal Delitua. Populasi pada penelitian ini berjumlah 486 orang siswa kelas X. Pengambilan sampel dengan mengunakan teknik purposive sampling berjumlah 35 orang siswa kelas X.AP-1. Berdasarkan hasil uji persyaratan diketahui bahwa data motivasi maupun hasil belajar matematika siswa berdistribusi normal. Data motivasi dengan skor rata-rata 99,2 sedangkan data hasil belajar matematika siswa dengan skor rata 19,6. Berdasarkan hasil analisis data dapat disimpulkan bahwa: (1) media komik matematika berpengaruh positif dan signifikan terhadap motivasi belajar matematika. Dimana hasil uji $\mathrm{t}$ diperoleh $\mathrm{t}_{\text {hitung }}=$ $3,1914>\mathrm{t}_{\text {tabel }}=1,692$. Indeks determinasi $\mathrm{I}=12,5 \%$, artinya dimana media komik matematika menyumbang $12,5 \%$ terhadap motivasi belajar matematika; (2) media komik matematika berpengaruh positif dan signifikan terhadap hasil belajar matematika. Berdasarkan hasil uji $\mathrm{t}$ diperoleh $\mathrm{t}_{\text {hitung }}=6,19>\mathrm{t}_{\mathrm{tabel}}=1,692$. Indeks determinasi $\mathrm{I}=$ $53,77 \%$, artinya dimana media komik matematika menyumbang 53,77\% terhadap hasil belajar matematika siswa.
\end{abstract}

Kata Kunci: media komik matematika, motivasi belajar, hasil belajar

\section{PENDAHULUAN}

Hasil belajar siswa yang masih rendah dapat diartikan kurang efektifnya proses pembelajaran. Penyebabnya dapat berasal dari siswa, guru, aktifitas pembelajaran, aktifitas siswa yang rendah, serta tidak adanya kesesuaian antara kemampuan siswa dengan cara penyajian materi sehingga matematika dirasakan sebagai pelajaran yang sulit untuk diterima. Dalam memajukan ilmu pengetahuan dan teknologi matematika 
sangat berperan karena semua ilmu pengetahuan dan teknologi memerlukan matematika. Hal ini berarti matematika perlu dikuasai oleh setiap siswa, sebab matematika mampu memberikan bekal penataan, penalaran dan pembentukan sikap mental. Mengingat pentingnya peran matematika, maka perlu memotivasi siswa dalam belajar matematika, sehingga pembelajaran matematika menjadi pembelajaran yang menyenangkan.

Proses pembelajaran adalah suatu kegiatan yang harus dilaksanakan sesuai dengan kurikulum. Di satu sisi guru diharapkan dapat menciptakan suasana yang kondusif dalam proses pembelajaran yang efektif dan efisien. Sedangkan disisi lain anak didik diharapkan dapat mengikuti proses pembelajaran dengan sebaik-baiknya. Guru harus menyadari apa yang sebaiknya dilakukan untuk menciptakan kondisi pembelajaran yang dapat menghantarkan anak didik kea rah tujuan pembelajaran. Disini tentu saja tugas guru berusaha menciptakan suasana belajar yang menyenangkan bagi semua anak didik. Namun usaha guru akan sia-sia apabila siswa yang diajarkan tidak termotivasi dalam belajar. Kreatifitas guru sebagai tenaga pendidik sangat membutuhkan pemahaman, penguasaan, dan pengalaman dalam pembelajaran siswanya. Pengalaman untuk mencobakan dan menerapkan berbagai strategi pembelajaran yang relevan dengan hasil belajar yang dicapai dapat memberikan hal-hal baru bagi guru maupun siswa. Kegiatan belajar yang bervariasi akan menyenangkan dan menantang segenap potensi siswa. Oleh sebab itu pemahaman dan kemampuan guru dalam menerapkan berbagai strategi pembelajaran yang bervariasi adalah sangat penting untuk meraih keberhasilan siswa.

Cockroft (Shadiq, 2007:3) mengemukakan tentang pentingnya matematika: Matematika perlu diajarkan kepada siswa karena (1) selalu digunakan dalam segala segi kehidupan; (2) Semua bidang studi memerlukan keterampilan matematika yang sesuai; (3) merupakan sarana komunikasi yang kuat, singkat, dan jelas; (4) dapat digunakan untuk menyajikan informasi dalam berbagai cara; (5) meningkatkan kepuasan terhadap usaha memecahkan masalah yang menantang. Selain itu menggunakan media pembelajaran, alat peraga dan sebagainya, juga sangat penting untuk keberhasilan siswa dalam proses pembelajaran.

Dalam kegiatan belajar mengajar guru berusaha menyampaikan sesuatu hal yang disebut pesan dan sebaliknya, dalam kegiatan belajar mengajar siswa juga berusaha memperoleh sesuatu hal. Peranan guru yang penting adalah sebagai penyusun program pembelajaran, pemberi informasi yang benar, pemberi fasilitas belajar yang baik, pembimbing siswa dalam pemerolehan informasi yang benar (Dimyanti dan Mudjiono, 2009:173). Guru dalam proses pembelajaran dituntut untuk lebih kreatif menentukan media yang tepat yang dapat dilakukan oleh media pembelajaran. Pembelajaran itu rumit apabila tidak didukung oleh media pembelajaran. Jika proses pembelajaran hanya bersifat ceramah saja tanpa menggunakan media, maka siswa akan kurang aktif dalam menerima pembelajaran. Salah satu penyebabnya adalah banyaknya materi yang harus dibahas padahal waktu hanya sedikit yang menyebabkan rendahnya hasil belajar yang diperoleh siswa di sekolah.

Pada awalnya guru dianggap sebagai satu-satunya penyampai informasi dan sumber belajar dikelas. Padahal, sesungguhnya media pembelajaran merupakan suatu alat bantu yang sangat berguna dalam proses belajar mengajar menurut Sudjana dan Rivai (Sundayana, 2014:8). Media dapat menjadi alat bantu yang dapat mewakili sesuatu yang tidak dapat disampaikan guru melalui kata-kata atau kalimat keefektifan daya serap siswa terhadap bahan pelajaran yang sulit dan rumit dapat terjadi dengan 
bantuan media sumber belajar. Sarana dan prasarasna sangat mempengaruhi hasil belajar Matematika di sekolah.

Dalam menyampaikan pelajaran dengan menggunakan media, media yang digunakan tidak harus mahal, tetapi dapat berupa cerita bergambar yang menarik seperti komik yang mudah diterima oleh siswa itu sendiri. Menurut Masdiono (Mastina, 2011:2) media komik merupakan bentuk media grafik dua dimensi, yaitu media yang dipakai menyangkut indera penglihatan. Media ini akan memberikan pengaruh terhadap perolehan kemampuan hasil belajar, karena mampu menarik perhatian dan minat, memperjelas ide, serta sederhana dalam penyampaian informasi.

Tujuan dari motivasi adalah untuk menggerakkan atau menggugah seseorang agar timbul keinginan dan kemauannya untu melakukan sesuatu sehingga dapat memperoleh hasil atau mencapai tujuan tertentu (Purwanto, 2010:73). Dimyanti dan Mudjiono (2009:86) menjelaskan bahwa motivasi dibedakan menjadi dua jenis, yaitu: 1) Motivasi primer adalah motivasi yang didasarkan pada motif-motif dasar. Motifmotif dasar tersebut umumnya berasal dari segi biologis atau jasmani manusia. Manusia adalah makhluk berjasmani sehingga prilakunya terpengaruh oleh Insting atau kebutuhan jasmani; 2) Motivasi skunder adalah motivasi yang dipelajari.

Menurut Sardiman (2011:83) motivasi yang ada pada diri setiap orang memiliki ciri-ciri sebagai berikut: a) Tekun menghadapi tugas (dapat bekerja terus menerus dalam waktu yang lama tidak pernah berhenti sebelum selesai; b) Ulet menghadapi kesulitan (tidak lekas putus asa) tidak memerlukan dorongan dari luar untuk berprestasi sebaik mungkin (tidak cepat puas dengan prestasi yang telah dicapainya); c) Menunjukkan minat terhadap bermacam-macam masalah untuk orang dewasa (misalnya, masalah pembangunan, agama, politik, ekonomi, keadilan, pembrantas korupsi, penentangan terhadap setiap tindak kriminal, moral dan sebagainya; d) Lebih senang bekerja sendiri; e) Cepat bosan pada tugas-tugas yang rutin (hal-hal yang bersifat mekanis, berulang-ulang begitu saja sehingga kurang kreatif); f) Dapat mempertahankan pendapatnya kalau sudah yakin akan sesuatu; g) Tidak mudah melepaskan yang diyakini itu; dan h) Senang mencari dan memecahkan masalah soalsoal.

Apabila seseorang memiliki ciri-ciri seperti diatas, berarti seseorang itu selalu memiliki motivasi yang cukup kuat. Ciri-ciri motivasi itu sangat penting dalam kegiatan belajar. Sebagai media pembelajaran, komik mempunyai sifat yang sederhana, jelas, mudah, dan bersifat personal. Komik diterbitkan dalam rangka tujuan komersial, dan edukatif meski tidak semua komik bersifat edukatif yang mempunyai unsur-unsur (Rohani, 2014:79) yaitu: 1) Sederhana, langsung, aksi-aksi yang cepat dan menggambarkan peristiwa-peristiwa yang mengandung bahaya; 2) Berisi unsur humor yang kasar, menggunakan bahasa percakapan; 3) Perhatikan kepada kriminalitas, kekuatan, keampuhan; dan 4) Adanya kecenderungan manusiawi yang universal terhadap pemujaan pahlawan.

Seno gumira ajidarma menyebut istilah komik berasal dari kata comic yang memiliki arti lucu. Biasanya berbentuk naratif dan terdapat pada halaman khusus dalam surat kabar. Namun perkembangan komik di Indonesia tak melulu dengan cerita-cerita lucu. Komikus pun banyak yang melahirkan karya secara mandiri tanpa harus dimuat terlebih dahulu. Susilana dan Riyana (2009:188) komik dapat didefinisikan sebagai bentuk kartun yang mengungkapkan karakter dan menerapkan suatu cerita dalam urutan yang erat hubungannya dengan gambar dan dirancang untuk memberikan hiburan kepada para pembaca. Pada awalnya komik diciptakan bukan 
untuk kegiatan pembelajaran, namun untuk hiburan semata. Begitu maraknya komik di masyarakat dan begitu tingginya kesukaan akan terhadap komik hal tersebut mengilhami untuk dijadikannya komik sebagai media pembelajaran. Salah satu kelebihan dari komik seperti penelitian yang dilakukan Thorndike, diketahui bahwa anak yang membaca komik lebih banyak misalnya dalam sebulan minimal satu buah buku komik maka sama dengan membaca buku-buku pelajaran dalam setiap tahunnya, hal ini berdampak pada kemampuan membaca siswa dan penguasaan kosa kata jauh lebih banyak dari siswa yang tidak menyukai komik.

Kelebihan komik yang lainnya adalah penyajiannya mengandung unsur visual dan cerita yang kuat. Ekspresi yang divisualisasikan membuat pemebaca terlibat secara emosional sehingga mebuat pembaca untuk terus membacanya hingga selesai. Hal inilah yang juga menginspirasi komik yang isinya materi-materi pelajaran. Kecenderungan yang ada siswa tidak begitu menyukai buku-buku teks apalagi yang tidak disertai gambar dan ilustrasi yang menarik. Padahal secara empirik siswa cenderung lebih menyukai buku yang bergambar, yang penuh warna dan divisualisasikan dalam bentuk realistis maupun kartun. Komik pembelajaran diharapkan mampu meningkatkan minat siswa untuk membaca sehingga pada akhirnya mampu meningkatkan hasil belajar siswa.

Rohani (2014) mengemukakan bahwa komik pembelajaran dalam dunia pendidikan bersifat edukatif dan menciptakan unsur penyampaian pesan yang jelas serta komunikatif. Komik adalah suatu kartun yang mengungkapkan sesuatu karakter dan memerankan cerita dalam urutan yang erat, dihubungkan dengan gambar dan dirancang untuk memberikan hiburan kepada pembaca. Komik matematika yang digunakan dalam penelitian ini merupakan komik yang disusun oleh penulis sendiri. Komik yang dibuat penulis dimodifikasi dari buku komik "why? Happy math". Komik yang dibuat penulis berisi tentang pelajaran invers matriks, dimana komik tersebut terdiri dari 23 halaman yang berceritakan perbincangan oleh 4 orang siswa yang membahas tentang pelajaran invers matriks. Hal ini dilakukan, mengingat belum ada komik matematika yang berisi materi matriks. Komik matematika yang beredar di pasaran lebih banyak untuk konsumsi peserta didik Sekolah Dasar (SD) dan Sekolah Menengah Pertama.

\section{METODE}

Lokasi penelitian ini adalah SMK Istiqlal Delitua semester genap tahun ajaran 2015/2016. Populasi penelitian adalah seluruh siswa kelas X SMK Istiqlal Delitua, yang terdiri dari 15 kelas. Dalam penelitian ini, penulis menggunakan teknik Purposive menjadi sampel penelitian adalah kelas X-AP.1 yang berjumlah 35 siswa berdasarkan hasil observasi pada guru matematika kelas X-AP.1 SMK Istiqlal Delitua. Adapun desain penelitiannya adalah sebagai berikut:

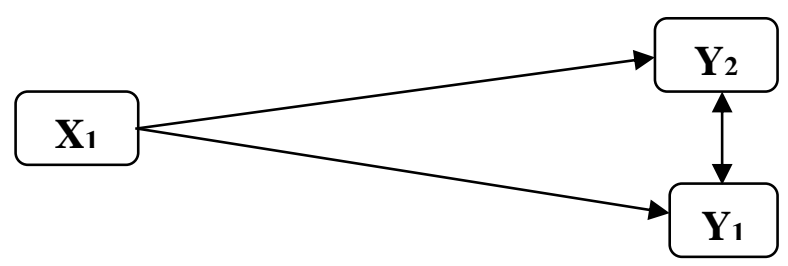

Gambar 1. Desain Penelitian 
Keterangan:

$\mathrm{X}_{1}$ : Perlakuan dengan media komik adalah variabel bebas

$\mathrm{Y}_{1}$ : Motivasi adalah variabel terikat pertama

$\mathrm{Y}_{2}$ : Hasil Belajar adalah variabel terikat kedua

\section{HASIL DAN PEMBAHASAN}

\section{Hasil}

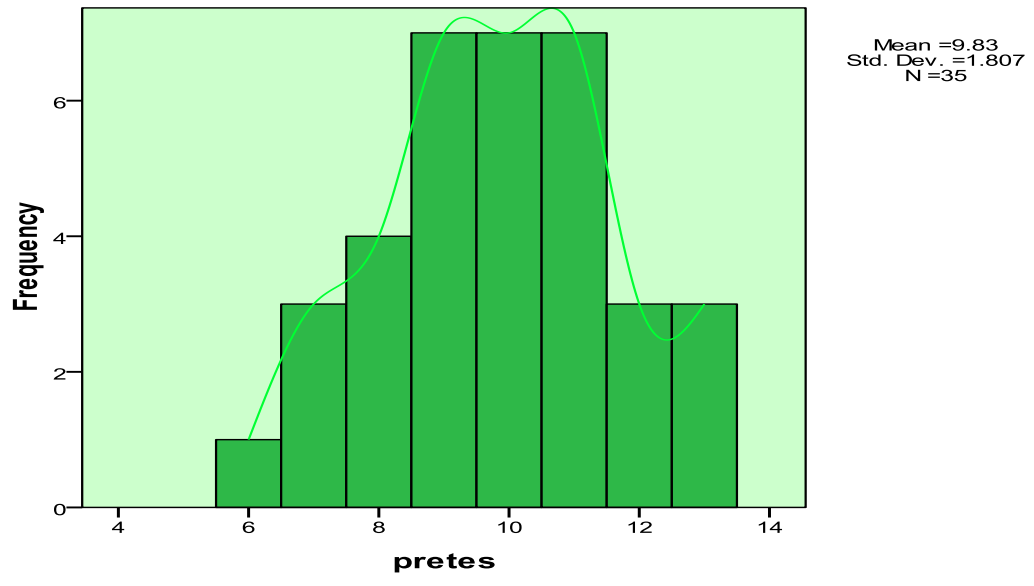

Gambar 2. Histogram Data Hasil Pretes

Histogram diatas merupakan data hasil pretes yang dilakukan sebelum menggunakan media komik adalah hasil pretes dari materi pembelajaran invers matriks. Dilihat dari grafik tersebut dengan nilai rata-rata 9,83 dan standart deviasi 1,807. Dari grafik tersebut dapat disimpulkan bahwa rendahnya hasil belajar siswa pada materi pembelajaran invers matriks.

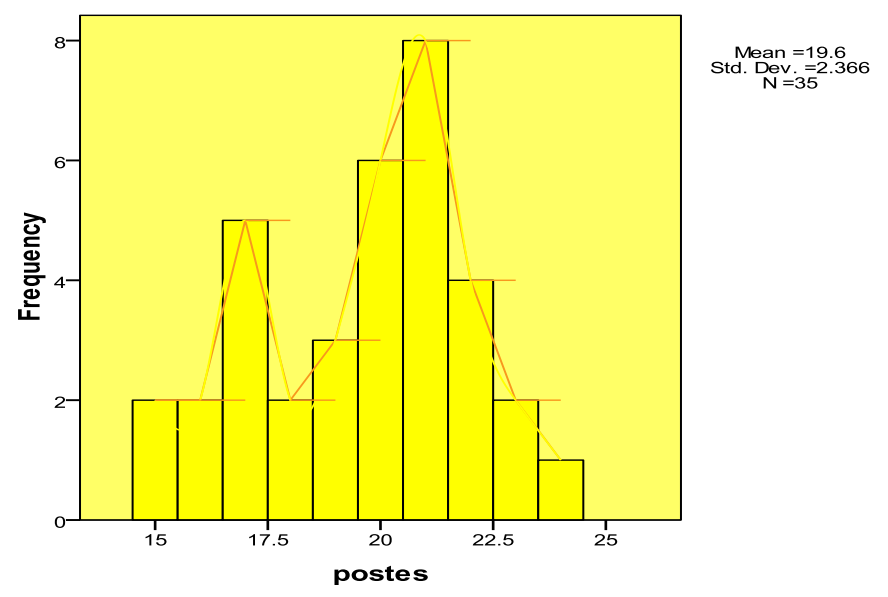

Gambar 3. Histogram Data Hasil Postes

Histogram diatas merupakan data hasil postes yang dilakukan setelah menggunakan media komik dari materi pembelajaran invers matriks untuk mengetahui tinggi rendahnya hasil belajar siswa dengan menggunakan media komik matematika. Dilihat dari grafik tersebut dengan nilai rata-rata 19,6 dan standart deviasi 2,366. Dari grafik tersebut dapat disimpulkan bahwa hasil belajar siswa pada materi pembelajaran 
invers matriks dengan menggunakan media komik meningkat yaitu memiliki pengaruh terhadap hasil belajar.

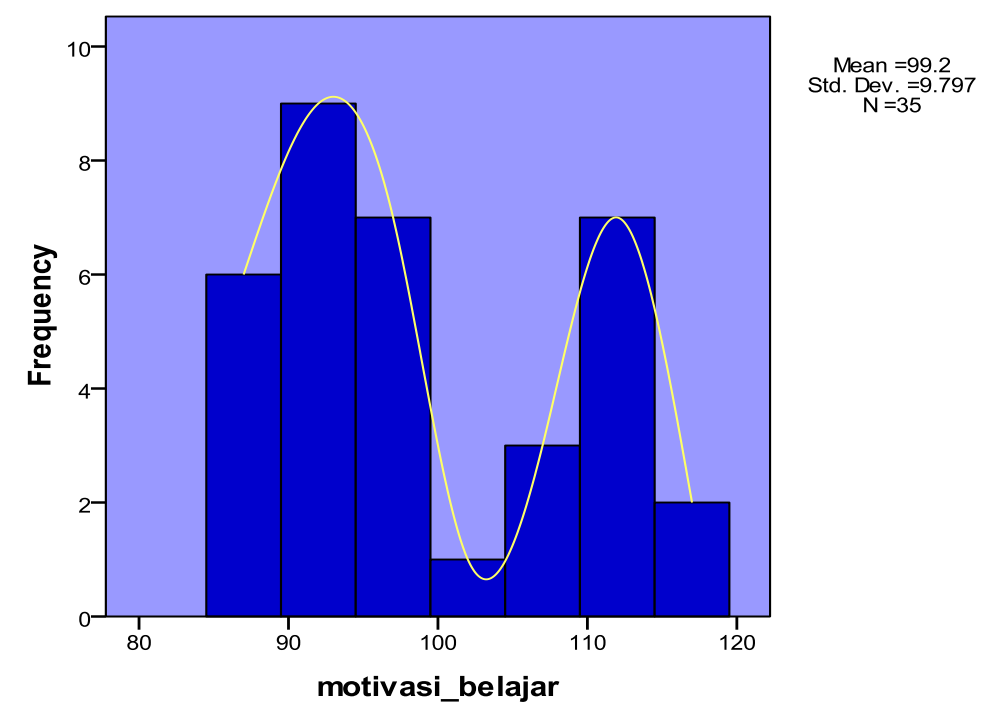

Gambar 4. Histogram Data Hasil Motivasi

Histogram diatas merupakan data hasil angket motivasi yang dilakukan setelah melakukan kegiatan pembelajaran menggunakan media komik dari materi pembelajaran invers matriks. Dilihat dari grafik dengan nilai rata-rata 99,2 dan standart deviasi 9,797. Dari grafik tersebut dapat disimpulkan bahwa semakin bervariasi media pembelajaran yang digunakan semakin tinggi tingkat motivasi belajar siswa. Berikut ini adalak hasil uji normalitas data Pretes, Postes dan Motivasi Belajar matematika Siswa.

Tabel 1. Hasil Uji Normalitas Data Hasil Pretes

\begin{tabular}{llr}
\hline \multicolumn{2}{c}{ One-Sample Kolmogorov-Smirnov Test } \\
\hline $\mathrm{N}$ & \multicolumn{1}{c}{ PRETES } \\
Normal Parametersa,,b & Mean & 9.83 \\
& Std. Deviation & 1.807 \\
Most Extreme Differences & Absolute & .113 \\
& Positive & .105 \\
& Negative & -.113 \\
Kolmogorov-Smirnov Z & .669 \\
Asymp. Sig. (2-tailed) & .762 \\
\hline a. Test distribution is Normal. \\
b. Calculated from data.
\end{tabular}

Hipotesis untuk uji normalitas adalah:

$\mathrm{H}_{0}$ : Data yang di uji berdistribusi normal

$\mathrm{H}_{\mathrm{a}}$ : Data yang di uji tidak berdistribusi normal

Pengambilan Keputusan:

Jika nilai signifikan variabel $\geq 0,05$, maka $\mathrm{H}_{0}$ diterima

Jika nilai signifikan variabel $<0,05$, maka $\mathrm{H}_{0}$ ditolak 
Dari hasil data diatas dapat disimpulkan bahwa pengujian normalitas dengan menggunakan bantuan SPSS 17 diperoleh nilai signifikan pada baris kolmogorovsmirnov dan kolom pretes adalah 0,762. Karena signifikansi variabel lebih dari 0,05 maka $\mathrm{H}_{0}$ diterima, sehingga dapat disimpulkan bahwa pretes berdistribusi normal.

Tabel 2. Hasil Uji Normalitas Data Hasil Postes

One-Sample Kolmogorov-Smirnov Test

\begin{tabular}{llr}
\hline & & POSTES \\
\hline Normal Parameters ${ }^{a, b}$ & Mean & 35 \\
& Std. Deviation & 19.60 \\
Most Extreme Differences Absolute & 2.366 \\
& Positive & .167 \\
& Negative & .121 \\
Kolmogorov-Smirnov Z & & -.167 \\
Asymp. Sig. (2-tailed) & .989 \\
\hline a. Test distribution is Normal. & .282 \\
b. Calculated from data. & \\
\end{tabular}

Hipotesis untuk uji normalitas adalah:

$\mathrm{H}_{0}$ : Data yang di uji berdistribusi normal

$\mathrm{H}_{\mathrm{a}}$ : Data yang di uji tidak berdistribusi normal

Pengambilan Keputusan:

Jika nilai signifikan variabel $\geq 0,05$, maka $\mathrm{H}_{0}$ diterima

Jika nilai signifikan variabel $<0,05$, maka $\mathrm{H}_{0}$ ditolak

Dari hasil data diatas dapat disimpulkan bahwa pengujian normalitas dengan menggunakan bantuan SPSS 17 diperoleh nilai signifikan pada baris kolmogorovsmirnov dan kolom postes adalah 0,282. Karena signifikansi variabel lebih dari 0,05 maka $\mathrm{H}_{0}$ diterima, sehingga dapat disimpulkan bahwa postes berdistribusi normal.

Tabel 3. Hasil Uji Normalitas Data Motivasi belajar

\begin{tabular}{llr}
\multicolumn{2}{c}{ One-Sample Kolmogorov-Smirnov Test } \\
\hline $\mathrm{N}$ & Motivasi_belajar \\
\hline Normal Parameters ${ }^{\mathrm{a}, \mathrm{b}}$ & Mean & 35 \\
& Std. Deviation & 99.20 \\
Most Extreme & Absolute & 9.797 \\
Differences & Positive & .197 \\
& Negative & .197 \\
Kolmogorov-Smirnov Z & -.130 \\
Asymp. Sig. (2-tailed) & 1.168 \\
\hline a. Test distribution is Normal. & .131 \\
\hline b. Calculated from data.
\end{tabular}

Hipotesis untuk uji normalitas adalah:

$\mathrm{H}_{0}$ : Data yang di uji berdistribusi normal

$\mathrm{H}_{\mathrm{a}}$ : Data yang di uji tidak berdistribusi normal 
Pengambilan Keputusan:

Jika nilai signifikan variabel $\geq 0,05$, maka $\mathrm{H}_{0}$ diterima

Jika nilai signifikan variabel $<0,05$, maka $\mathrm{H}_{0}$ ditolak

Dari hasil data diatas dapat disimpulkan bahwa pengujian normalitas dengan menggunakan bantuan SPSS 17 diperoleh nilai signifikan pada baris kolmogorovsmirnov dan kolom motivasi belajar adalah 0,131 . Karena signifikansi variabel lebih dari 0,05 maka $\mathrm{H}_{0}$ diterima, sehingga dapat disimpulkan bahwa angket motivasi berdistribusi normal.

Tabel 4. Data Hasil Uji Linieritas Media Komik terhadap Hasil belajar

ANOVA Table

\begin{tabular}{|c|c|c|c|c|c|c|c|}
\hline & & & $\begin{array}{l}\text { Sum of } \\
\text { Squares }\end{array}$ & $d f$ & $\begin{array}{l}\text { Mean } \\
\text { Square }\end{array}$ & $\mathrm{F}$ & Sig. \\
\hline \multirow{5}{*}{$\begin{array}{l}\text { hasilbelajar * } \\
\text { mediakomik }\end{array}$} & \multirow{3}{*}{$\begin{array}{l}\text { Between } \\
\text { Groups }\end{array}$} & (Combined) & 112.031 & 7 & 16.004 & 5.514 & .001 \\
\hline & & Linearity & 102.401 & 1 & 102.401 & 35.280 & .000 \\
\hline & & $\begin{array}{l}\text { Deviation } \\
\text { from } \\
\text { Linearity }\end{array}$ & 9.630 & 6 & 1.605 & .553 & .763 \\
\hline & \multicolumn{2}{|c|}{ Within Groups } & 78.369 & 27 & 2.903 & & \\
\hline & \multicolumn{2}{|l|}{ Total } & 190.400 & 34 & & & \\
\hline
\end{tabular}

Hipotesis untuk uji linieritas adalah:

$\mathrm{H}_{0}$ : Terdapat hubungan yang linier antara variabel bebas dengan variabel terikat.

$\mathrm{H}_{\mathrm{a}}$ : Tidak terdapat hubungan yang linier antara variabel bebas dengan variabel terikat.

Pengambilan Keputusan:

Jika $\mathrm{F}$ hitung $\geq \mathrm{F}$ tabel, maka $\mathrm{H}_{0}$ ditolak

Jika $\mathrm{F}$ hitung $<\mathrm{F}$ tabel, maka $\mathrm{H}_{0}$ diterima

Dari hasil data diatas dapat disimpulkan bahwa pengujian linieritas dengan menggunakan bantuan SPSS 17 diperoleh nilai signifikansi pada linierity media komik dengan hasil belajar sebesar 0,000. Karena signifikansi kurang dari 0,05 maka $\mathrm{H}_{0}$ diterima, sehingga dapat disimpulkan bahwa antara variabel media komik dengan variabel hasil belajar matematika terdapat hubungan yang linier. Berikut ini adalah hasil uji homigenitas data hasil belajar dan motivasi belajar matematika siswa.

Tabel 5. Hasil Uji Homigenitas Data Hasil Belajar dan Motivasi Belajar Matematika Siswa

Test of Homogeneity of Variances

\begin{tabular}{|c|c|c|c|}
\hline Levene Statistic & $\mathrm{df1}$ & $\mathrm{df2}$ & Sig. \\
\hline 2.433 & 6 & 27 & .052 \\
\hline
\end{tabular}

Pengambilan Keputusan:

Jika nilai signifikan variabel $\geq 0,05$, maka dikatakan bahwa varian dari dua atau lebih kelompok populasi data adalah sama. 
Jika nilai signifikan variabel $<0,05$, maka dikatakan bahwa varian dari dua atau lebih kelompok populasi data adalah tidak sama.

Dari hasil data diatas dapat disimpulkan bahwa pengujian homogenitas dengan menggunakan bantuan SPSS 17 diperoleh nilai signifikansi variabel hasil belajar (Y) berdasarkan variabel Media komik $(X)=0,052 \geq 0,05$, maka variabel hasil belajar (Y) berdasarkan variabel Media komik (X) adalah sama.

\section{Pembahasan}

Berdasarkan analisis data yang telah disajikan dalam tabel seperti yang telah dipaparkan dihalaman sebelumnya menunjukkan bahwa:

1. Terdapat pengaruh media komik matematika terhadap motivasi belajar matematika siswa di SMK Istiqlal Delitua. Ini membuktikan bahwa media komik dapat membantu dalam pembelajaran yang selama ini kurang diperhatikan untuk meningkatkan motivasi belajar siswa dan ternyata media komik matematika memiliki pengaruh terhadap motivasi belajar matematika siswa di sekolah. Hal ini sesuai dengan teori Masdiono yang menyatakan bahwa media komik merupakan bentuk media grafis, yaitu media yang dipakai menyangkut indera penglihatan, media yang memberikan pengaruh besar terhadap perolehan kemampuan hasil belajar karena mampu menarik perhatian dan minat, memperjelas ide, serta sederhana dalam penyampaian informasi, dengan media komik peserta didik lebih termotivasi dengan media komik tersebut. Secara langsung juga terlihat kebiasaan peserta didik yang berubah drastis lebih perhatian terhadap pelajaran matematika saat belajar dengan munculnya media komik ini merubah siswa untuk lebih giat dan besarnya rasa ingin tahu terhadap pelajaran matematika tersebut, sehingga termotivasi siswa dalam belajar matematika. Dengan memilih media komik dalam pembelajaran matematika dapat menarik semangat siswa supaya temotivasi untuk lebih serius dalam belajar matematika agar siswa tidak merasa bosan dalam belajar matematika. Hal ini ditunjukkan dengan adanya hasil penelitian yaitu $t_{\text {hitung }}$ lebih besar dari $t_{\text {tabel }}$. Diperoleh nilai $t_{\text {hitung }}=3,1914>t_{\text {tabel }}$ (pada taraf signifikansi 0,05 ) yang nilainya adalah 1,692 . Sehingga $H_{0}$ ditolak, jadi koefisien korelasi sebesar 0,35368 adalah signifikan dengan besarnya kontribusi 12,5089 $\%$.

2. Terdapat pengaruh media komik matematika terhadap hasil belajar matematika siswa kelas X-AP.1 di SMK Istiqlal Delitua. Hal ini ditunjukkan dengan adanya hasil penelitian yaitu $t_{\text {hitung }}$ lebih besar dari $t_{\text {tabel }}$. Diperoleh nilai $t_{\text {hitung }}=$ $6,19>t_{\text {tabel }}$ (pada taraf signifikansi 0,05 ) yang nilainya adalah 1,692 . Hal ini sesuai dengan teori yang menyatakan bahwa media dapat menjadi alat bantu yang dapat mewakili sesuatu yang tidak disampaikan guru melaui kata-kata atau kalimat keefektifan daya serap siswa terhadap bahan pelajaran yang sulit dan rumit dapat terjadi dengan bantuan media sumber belajar. Sarana dan prasarana sangat mempengaruhi hasil belajar matematika disekolah, dengan munculnya media komik ini dapat merubah siswa untuk lebih giat dan besarnya rasa ingin tahu terhadap pelajaran matematika dan termotivasi siswa dalam belajar matematika sehingga dapat meningkatkan hasil belajar siswa. Oleh karena itu, media komik yang digunakan penulis mampu meningkatkan minat belajar siswa untuk membaca sehingga pada akhirnya mampu meningkatkan hasil belajar siswa. Jadi dapat disimpulkan bahwa media komik matematika juga mempunyai pengaruh yang bisa 
menimbulkan adanya kenaikan hasil belajar matematika siswa dengan koefisien korelasi sebesar 0,733361 adalah signifikan dengan besarnya kontribusi 53,77\%.

\section{KESIMPULAN}

Berdasarkan pembahasan hasil penelitian tentang pengaruh penggunaan media komik matematika terhadap motivasi dan hasil belajar matematika siswa kelas X.AP1 di SMK Istiqlal Delitua. Dari pembahasan keseluruhan penulis dapat menyimpulkan sebagai berikut:

1. Ada pengaruh yang positif dan signifikan media komik matematika terhadap motivasi belajar matematika siswa kelas X.AP-1 di SMK Istiqlal Delitua Tahun Pembelajaran 2015-2016. Hal ini dapat dibuktikan dengan adanya hasil penelitian yaitu: $t_{\text {hitung }}=3,1914>t_{\text {tabel }}$ (pada taraf signifikansi 0,05 ) yang nilainya adalah 1,692. Sehingga $H_{0}$ ditolak, jadi koefisien korelasi sebesar 0,35368 adalah signifikan dengan besarnya kontribusi $12,5089 \%$.

2. Ada pengaruh yang positif dan signifikan media komik matematika terhadap hasil belajar matematika siswa kelas X.AP-1 di SMK Istiqlal Delitua Tahun Pembelajaran 2015-2016. Hal ini dapat dibuktikan dengan adanya hasil penelitian yaitu: $t_{\text {hitung }}=6,19>t_{\text {tabel }}$ (pada taraf signifikansi 0,05 ) yang nilainya adalah 1,692. Jadi koefisien korelasi sebesar 0,733361 adalah signifikan dengan besarnya kontribusi $53,77 \%$.

\section{DAFTAR PUSTAKA}

Dimyanti dan Mujiono. 2009. Belajar dan Pembelajaran. Jakarta: Rineka Cipta. Kim Tae Wan. 2009. Why? Happy Math 5. Jakarta: Gramedia.

Purwanto, N. 2010. Psikologi Pendidikan. Bandung: Remaja Rosdakarya.

Shadiq, F. 2007. Apa dan Mengapa Matematika Begitu Penting?. Yogyakarta: Widyaiswara PPPPTK Matematika.

Sardiman. 2011. Interaksi dan motivasi Belajar Mengajar. Jakarta: PT. Raja Grafindo Persada.

Sundayana, R. 2014. Media dan Alat Peraga dalam Pembelajaran Matematika. Bandung: Alfabeta.

Susilana, R dan Riyana, C. 2009. Media Pembelajaran. Bandung: Wacana Prima. 